\title{
Cyclic variation in concentrations of protein and hexose in human uterine flushings collected by an improved technique
}

\begin{abstract}
J. B. Maathuis* and R. J. Aitken
M.R.C. Unit of Reproductive Biology, 23 Chalmers Street, Edinburgh EH3 9EW, U.K.

Summary. Uterine flushings were obtained from fertile women at various stages of the menstrual cycle. A technique was used which excluded contamination with cervical mucus and significantly lowered contamination with blood in comparison with an established technique. Contamination of the uterine flushings with seminal plasma and tubal fiuid was also prevented.

The concentrations of protein and hexose in the uterine flushings, corrected for contamination with plasma, were significantly lower in the secretory stages than in the proliferative stages of the cycle. It is concluded that proteins and carbohydrates are present within the uterine lumen not only after ovulation but also during the preovulatory period.
\end{abstract}

\section{Introduction}

Uterine luminal fluid may influence the transport, metabolism and capacitation of spermatozoa (Kirton \& Hafs, 1965; Iritani, Gomes \& VanDemark, 1969; Lewis \& Ketchel, 1973), and affect blastocyst metabolism and expansion (Lutwak-Mann, Boursnell \& Bennet, 1960; Brinster, 1973). Attempts have been made to study this fluid in man with a variety of techniques (see Discussion), but contamination with blood, cervical mucus and seminal plasma have rarely been taken into account and there is little conclusive information on human uterine fluid and possible cyclic changes in its composition.

The present study was to determine the concentrations of total protein and total hexose in uterine flushings obtained, by means of an improved technique, from normal fertile women at various stages of the menstrual cycle.

\section{Materials and Methods}

\section{Subjects}

Informed written consent was obtained from 55 parous women aged 22-45 years (median 31 years) who requested laparoscopic tubal sterilization at the Gynaecological Clinic, Royal Infirmary, Edinburgh. All subjects had a history of regular menstrual cycles $(29 \pm 3$ days) and were requested to abstain from intercourse during the week before the sterilization. The stage of the menstrual cycle was assessed from the dates of the last and next menstrual period, the plasma concentrations of oestradiol and progesterone at the time of surgery, the appearance of the ovaries at laparoscopy and the endometrial histology, as previously described (Maathuis, Van Look \& Michie, 1978). The 7 stages recognized were early (EP), mid- (MP) and late proliferative (LP); early (ES), mid- (MS), and late secretory (LS) and late secretory-menstruating stage (LSm).

\section{Flushing procedure}

The uterine cervix was visualized with a speculum, the anterior cervical lip was grasped and the cervical os was cleaned with sterile dry gauze. A bimanual pelvic examination was not done before

\footnotetext{
*Present address: Department of Obstetrics and Gynaecology, Leiden University Hospital, Rijnsburgerweg 10, Leiden, The Netherlands.
} 
introduction of the flushing device. A 14-gauge Foley 3-way balloon catheter (cat. no. 41-825-10: Eschmann, Shoreham-by-Sea, U.K.) was wrapped in a polythene sheath (width $19 \mathrm{~mm}$, thickness $30 \mathrm{~nm}$; Mackinnon \& Hay, Edinburgh), which was heat-sealed at one end, to avoid contamination by endocervical mucus. The rigidity required for introduction of the device was effected by an intraluminal metal introducer (diameter $1 \mathrm{~mm}$; length $42 \mathrm{~cm}$, excluding the circular distal grip made to prevent perforation of the catheter by the introducer). When the tip of the device had reached the uterine fundus, the sheath was withdrawn thus breaking the heat-seal. The metal introducer was removed and the balloon was inflated within the uterine cavity with $1 \mathrm{ml}$ sterile $0 \cdot 154 \mathrm{M}-\mathrm{NaCl}$ solution. This amount was selected because it is well below the volume of the uterus (Weisman, 1951) and was sufficient to retain the catheter and avoid leakage during flushing. Because there could be no loss of fluid through the coagulated Fallopian tubes, the quantity of fluid recovered always exceeded $95 \%$ of the initial flushing volume.

In a pilot study uterine flushings $(6 \mathrm{ml})$ were obtained from 8 women (1 MP, $1 \mathrm{LP}, 4 \mathrm{MS}, 2 \mathrm{LS})$ with the Gravlee Jet washer (Becton, Dickinson \& Co, Rutherford, New Jersey, U.S.A.; Gravlee, 1969). The same volume and the Foley catheter were used to collect the flushings from the first 6 women in the actual study group (1 EP, 1 LP, 2 MS, 2 LS). The flushing volume in the remaining 49 subjects was $10 \mathrm{ml}$. In all cases the uterine cavity was flushed with $0 \cdot 154 \mathrm{M}$ sterile $\mathrm{NaCl}$ solution under minimal positive pressure. Immediately after collection $1 \mathrm{ml}$ of the flushings was transferred into a tube containing EDTA. This aliquot was twice frozen and thawed to effect haemolysis and was subsequently analysed for haemoglobin $(\mathrm{Hb})$. The remaining fluid was centrifuged at $1800 \mathrm{~g}$ for $10 \mathrm{~min}$ at $4^{\circ} \mathrm{C}$. The supernatant was stored at $-20^{\circ} \mathrm{C}$ until analysis.

\section{Estimations in peripheral blood and plasma}

Haemoglobin and packed cell volume (PCV) were measured in a Coulter counter (Model S; Coulter Electronics, Harpenden, U.K.).

Total protein was estimated with the biuret reagent (Gornall, Bardawill \& David, 1949).

\section{Estimations in uterine flushings}

Haemoglobin was estimated with a modified benzidine technique (Hanks, Cassell, Ray \& Chaplin, 1960). The accuracy was assessed by measuring the Hb concentration of dilutions $(1: 250$ and $1: 1250$ ) of blood with a known $\mathrm{Hb}$ content in $0 \cdot 154 \mathrm{M}-\mathrm{NaCl}$. The mean ( \pm s.d.) values for samples with a calculated $\mathrm{Hb}$ value of $0.604 \mathrm{mg} / \mathrm{ml}$ and $0.121 \mathrm{mg} / \mathrm{ml}$ were $0.643 \pm 0.008 \mathrm{mg} / \mathrm{ml}(n=4)$ and $0.121 \pm 0.019 \mathrm{mg} / \mathrm{ml}(n=4)$, respectively.

Total protein. Total protein was measured with the Folin phenol reagent (Lowry, Rosebrough, Farr \& Randall, 1951) and BSA was used for the standard curve.

Calculation of blood contamination in uterine flushings. The extent to which each uterine flushing was contaminated with blood, expressed as $\mathrm{mg}$ plasma protein $/ \mathrm{ml}$ uterine flushing $(y)$, was calculated from the $\mathrm{Hb}$ content, $\mathrm{PCV}$ and total protein concentration of blood, and the $\mathrm{Hb}$ concentration of the uterine flushing by the formula:

$$
y=\frac{100-\mathrm{PCV}}{100} \times \frac{\mathrm{Hb} \text { of uterine flushing }(\mathrm{mg} / \mathrm{ml})}{\mathrm{Hb} \text { of blood }(\mathrm{mg} / \mathrm{ml})} \times \text { total protein }(\mathrm{mg} / \mathrm{ml}) .
$$

This approach assumes (1) that the PCV of intrauterine haemorrhage caused by trauma is identical to that of peripheral blood and (2) that the normal concentration of $\mathrm{Hb}$ in uterine fluid is nil. The concentration of 'uterine' protein was calculated by subtracting $y$ from the total protein concentration in each uterine flushing.

Total hexose. Total hexose was measured in plasma and in the uterine flushings with the method of Trevelyan \& Harrison (1952) by using glucose as the standard. The contribution of hexose from blood was calculated as described for protein. 


\section{Statistical analysis}

As results did not show a normal distribution, the non-parametric tests of Wilcoxon and Spearman's rank correlation were used (Snedecor \& Cochran, 1967).

\section{Flushing procedure}

\section{Results}

Whenever the Gravlee Jet washer was used, cervical mucus was detected in the distal opening of the device. The contamination with plasma protein in the flushings collected with this device (mean \pm s.e.m.: $0.885 \pm 0.123 \mathrm{mg} / \mathrm{ml}, n=8$ ) was significantly higher than in the 6 samples collected in $6 \mathrm{ml}$ saline with the Foley catheter $(0.365 \pm 0.123 \mathrm{mg} / \mathrm{ml} ; P<0.01)$. Collection failed in 3 patients (1 LS, $2 \mathrm{LSm}$ ) and $\mathrm{Hb}$ was not measured in 1 sample. The results from 4 subjects (1 EP, $1 \mathrm{MP}, 1 \mathrm{LP}$, $1 \mathrm{ES})$ are excluded from the data in the following sections because the contamination with plasma protein was exceedingly high $(>2 \mathrm{mg} / \mathrm{ml})$.

\section{Protein and hexose concentrations in uterine flushings}

The total protein concentration of the uterine flushings (Text-fig. 1) was not correlated with the extent of contamination with plasma protein $\left(\mathrm{R}_{s}=0.25 ; P>0.05\right)$. The concentrations of contamination protein and 'uterine' protein in the ES, MS and LS groups combined were significantly lower than

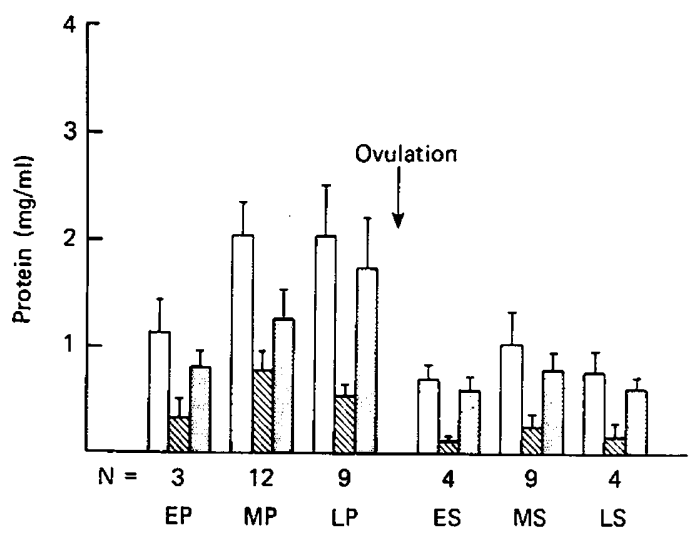

Text-fig. 1. Mean ( \pm s.e.m.) concentrations in uterine flushings of total protein (open bars), protein contamination from blood (hatched bars) and uterine protein (stippled bars) in relation to the stage of the menstrual cycle: EP, MP and LP refer to the early, mid- and late proliferative stages; ES, MS and LS to the early, mid- and late secretory stages.

Table 1. Mean \pm s.e.m. concentrations of total hexose in uterine flushings from women at different stages of the menstrual cycle

\begin{tabular}{lcc}
\hline Stage of cycle & $\begin{array}{c}\text { No. of } \\
\text { flushings }\end{array}$ & $\begin{array}{c}\text { Hexose } \\
(\mathrm{mg} / \mathrm{ml})\end{array}$ \\
\hline $\begin{array}{l}\text { Proliferative } \\
\text { Early }\end{array}$ & 3 & $0.63 \pm 0.20$ \\
$\quad$ Mid & 10 & $1.10 \pm 0.08$ \\
$\quad$ Late & 8 & $1.10 \pm 0.21$ \\
Secretory & & \\
$\quad$ Early & 4 & $0.50 \pm 0.13$ \\
$\quad$ Mid & 7 & $0.87 \pm 0.23$ \\
Late & 4 & $0.80 \pm 0.34$ \\
\hline
\end{tabular}


Table 2. Summary of the methods used in the literature to obtain specimens of uterine fluid from women at different stages of the menstrual cycle

\begin{tabular}{|c|c|c|c|c|c|}
\hline \multirow[b]{2}{*}{$\begin{array}{l}\text { Collection method } \\
\text { and reference }\end{array}$} & \multirow[b]{2}{*}{ Technique or device } & \multirow[b]{2}{*}{$\begin{array}{l}\text { No. of } \\
\text { subjects }\end{array}$} & \multicolumn{3}{|c|}{ Contamination } \\
\hline & & & Semen & $\begin{array}{l}\text { Cervical } \\
\text { mucus }\end{array}$ & Blood \\
\hline \multicolumn{6}{|c|}{ Collection chamber left in uterus } \\
\hline Douglas et al. (1970) & $\begin{array}{l}\text { Dialysis tubing, o.d. } 6 \mathrm{~mm} \text {, } \\
\text { length } 2.5 \mathrm{~cm} \text {, with polyvinyl } \\
\text { pyrridolone in uterus for } 24 \mathrm{~h}\end{array}$ & 60 & $?$ & \pm & $?$ \\
\hline Edwards et al. (1968) & $\begin{array}{l}\text { Nylon fenestrated chamber, o.d. } \\
3.2 \mathrm{~mm} \text {, length } 2.7 \mathrm{~cm} \text {, filled } \\
\text { with cellulose ester, left in } \\
\text { uterus for } 12 \mathrm{~h}\end{array}$ & 3 & $?$ & \pm & $\begin{array}{r}1 \text { out of } 3 \\
\text { samples }\end{array}$ \\
\hline Hall et al. (1965) & $\begin{array}{l}\text { Tubular polyethylene collector } \\
\text { left in uterus for } 48 \mathrm{~h}\end{array}$ & 33 & $?$ & \pm & $?$ \\
\hline \multicolumn{6}{|l|}{ Collection at operation } \\
\hline Beier et al. (1970) & Flushing with saline & ? & ? & ? & $?$ \\
\hline Bernstein et al. (1971) & $\begin{array}{l}\text { Drops of saline placed on endo- } \\
\text { metrium of transsected opera- } \\
\text { tion specimens with syringe } \\
\text { and needle. Several aspirates } \\
\text { pooled }\end{array}$ & 75 & $?$ & $?$ & All samples \\
\hline Clemetson et al. (1973) & $\begin{array}{l}\text { Puncture into uterine cavity with } \\
22 \text {-gauge needle during opera- } \\
\text { tion. Positive pressure flushing } \\
\text { with } 3 \mathrm{ml} 5 \%(\mathrm{w} / \mathrm{v}) \text { dextrose }\end{array}$ & 39 & ? & - & $\begin{array}{l}\text { Calculated from } \\
\text { amount of } \\
\text { broken red } \\
\text { cells and \% } \\
\text { haemolysis }\end{array}$ \\
\hline Kulangara (1976) & Direct aspiration & 5 & $?$ & $?$ & $\begin{array}{l}\text { All samples had } \\
\text { a red tinge }\end{array}$ \\
\hline Parr et al. (1976) & $\begin{array}{l}\text { Lens paper strips placed on } \\
\text { endometrium of transsected } \\
\text { operation specimens }\end{array}$ & 24 & $?$ & - & $\begin{array}{l}\text { Small amount of } \\
\text { blood often } \\
\text { present }\end{array}$ \\
\hline \multicolumn{6}{|l|}{ Transcervical collection } \\
\hline Kar et al. (1968) & Plastic IUD inserter & 44 & $?$ & + & $\begin{array}{l}\text { Hb contamina- } \\
\text { tion } 20-30 \%\end{array}$ \\
\hline Shirai et al. (1972) & $\begin{array}{l}\text { Rubber catheter, o.d. } 4 \mathrm{~mm} \\
\text { length } 6-7 \mathrm{~cm}\end{array}$ & 32 & $?$ & + & $?$ \\
\hline \multicolumn{6}{|l|}{ Negative pressure } \\
\hline Roberts et al. (1976) & $\begin{array}{l}\text { Gravlee Jet washer } 20-30 \mathrm{ml} \\
\text { saline }\end{array}$ & 32 & $?$ & + & $?$ \\
\hline $\begin{array}{l}\text { ?Wolf \& Mastroianni } \\
\quad(1975)\end{array}$ & $\begin{array}{l}\text { Weisman double lumen can- } \\
\text { nula (specifications not given), } \\
3-5 \mathrm{ml} \text { saline }\end{array}$ & 41 & \pm & \pm & $\begin{array}{l}6 \text { out of } 41 \\
\text { centrifuged } \\
\text { samples } \\
\text { positive for } \\
\mathrm{Hb}\end{array}$ \\
\hline $\begin{array}{l}\text { Positive pressure } \\
\text { ?Daniel (1973) }\end{array}$ & $\begin{array}{r}\text { Gravlee Jet washer, } 10 \mathrm{ml} \\
\text { saline }\end{array}$ & 2 & - & + & $?$ \\
\hline Joshi et al. (1970) & $\begin{array}{l}\text { Polyethylene catheter in endo- } \\
\text { metrial curette, tip covered by } \\
\text { fenestrated rubber tubing o.d. } \\
3 \mathrm{~mm}\end{array}$ & 60 & $?$ & \pm & $\begin{array}{l}\text { All samples, } \\
\text { various } \\
\text { amounts }\end{array}$ \\
\hline Present study & $\begin{array}{l}\text { Foley 3-way balloon catheter, } \\
\text { o.d. } 5 \mathrm{~mm} \text {, wrapped in poly- } \\
\text { thene sheath, } 6 \text { or } 10 \mathrm{ml} \text { saline }\end{array}$ & 51 & - & - & $\begin{array}{l}\text { Calculated for } \\
\text { each sample } \\
\text { from } \mathrm{Hb} \\
\text { content }\end{array}$ \\
\hline
\end{tabular}

o.d. = outer diameter; + , likely; \pm , possible; - , unlikely; ?, not mentioned or not clear. 
those in the EP, MP and LP groups combined $(P=0.0001$ and $P<0.02$ (Wilcoxon), respectively) The concentration of 'uterine' protein in the LP group did not differ significantly from that in the EP group.

The concentrations of hexose in relation to the stage of the menstrual cycle are shown in Table 1. The amount of hexose derived from blood was small in all cases (range $0.001-0.025 \mathrm{mg} / \mathrm{ml}$ ) and the values have not been corrected for contamination. The concentrations of hexose in the proliferative stages were together significantly higher $(P<0.02$, Wilcoxon) than in those collected after ovulation.

\section{Discussion}

The techniques used previously to obtain specimens of human uterine fluid are listed in Table 2. Intraluminal devices are known to alter the uterine environment (Peplow, Breed \& Eckstein, 1973a) and results obtained with intrauterine chambers probably do not reflect physiological conditions. Specimens collected during or after surgery may be affected by uterine pathology and by manipulations during the operation. Contamination with semen has only been excluded by the experimental design of Daniel (1973) and in the present study. Cervical mucus was detected in all instances when we used the Gravlee Jet washer but not when the Foley catheter was employed. The former device is of limited value in studies of this kind not only because of the contamination with mucus and blood, but also because of the questionable efficacy of a flushing procedure using negative pressure (Peplow, Breed, Jones \& Eckstein, 1973b).

At present accurate information on the volume of fluid in the human uterus throughout the menstrual cycle is not available. Therefore the concentrations of protein and hexose in the uterine fluid cannot be deduced from our measurements in the flushings. Clemetson, Kim, de Jesus, Mallikarjuneswara \& Wilds (1973) measured the volume of human uterine fluid indirectly and reported a slight decrease after ovulation. A decline in the volume of uterine fluid could therefore be the reason why we found lower concentrations of protein and hexose in the flushings collected after ovulation. Increased viscosity of uterine fiuid during the secretory stages, which in rabbits has been shown to be an effect of progesterone (Lutwak-Mann et al., 1960), may have reduced flushing efficacy and this could also partly explain the observed decreased concentrations of protein and hexose in the flushings collected in the ES, MS and LS stages.

Whatever the reason, in man, as in the baboon (Peplow et al., 1973b), significantly lower amounts of protein were obtained per uterus in the secretory stages of the cycle than during the proliferative stages. This finding does not seem to support the view that secretion takes place only during the postovulatory period. Clemetson et al. (1973) and Clemetson, Verma \& De Carlo (1977) have suggested that the term 'secretory' may even be inappropriate for the human postovulatory endometrium, but this suggestion does not seem to be fully supported by the data of Clemetson et al. (1973), and histochemical (Hester, Kellet, Spicer, Williamson \& Pratt-Thomas, 1970) and ultrastructural (Nilsson, 1962a; Wynn \& Woolley, 1967) findings are also contradictory.

Other workers have found consistent evidence of endometrial secretion during the proliferative stages (Nilsson, 1962b; Wynn \& Harris, 1967) and so the relatively high amounts of protein and hexose flushed from uteri during the preovulatory period may have been partly due to cellular secretory activity. Transudation may also have contributed to the intraluminal protein content (Kulangara, 1976), because oestrogen increases the permeability of endometrial blood vessels (Pappas \& Blanchette, 1965; Martin, Hallows, Finn \& West, 1973). Increased transudation during the follicular (oestrogenic) phase results in an accumulation of uterine fluid in rabbits (Lutwak-Mann et al., 1960) and possibly also in women (Clemetson et al., 1973). The rate of transudation and secretion must exceed the rate of absorption during that period. Progesterone may influence this dynamic equilibrium by affecting both transudation and secretion (Wynn \& Woolley, 1976; Clemetson et al., 1977).

The present study defines criteria for the collection and assessment of uterine flushings in women and shows that (1) the human uterine environment contains considerable quantities of proteins and carbohydrates at all stages of the cycle, and (2) during the preovulatory period greater amounts of protein and hexose are present within the uterine lumen than after ovulation, suggesting that the term 'proliferative' may be inappropriate for this stage of the cycle. 
We thank Dr S. H. Davies, Department of Haematology, Royal Infirmary, Edinburgh, for advice and assistance with the $\mathrm{Hb}$ measurements in uterine flushings. The help and encouragement of Professor D. T. Baird and Professor R. V. Short are gratefully acknowledged. J.B.M. was supported by a WHO Research Training Grant, R.J.A. by a M.R.C. Postdoctoral Fellowship.

\section{References}

Beier, H.M., Petry, G. \& Kuhnel, W. (1970) Endometrial secretion and early mammalian development. In Mammalian Reproduction, pp. 264-285. Eds A. Gibian \& E. J. Plotz. Springer, Berlin.

Bernstein, G.S., Aladjem, F. \& Chen, S. (1971) Proteins in human endometrial washings. A preliminary report. Fert. Steril. 22, 722-726.

BRINSTER, R.L. (1973) Nutrition and metabolism of the ovum, zygote, and blastocyst. In Handbook of Physiology, Section 7, vol. 2, part 2, pp. 165-185. Eds R. O. Greep \& E. B. Astwood. Williams and Wilkins, Baltimore.

Clemetson, C.A.B., Kim, J.K., De Jesus, T.P.S., Mallikarjuneswara, V.R. \& Wilds, J.H. (1973) Human uterine fluid potassium and the menstrual cycle. J. Obstet. Gynaec. Br. Commonw. 80, 553-561.

Clemetson, C.A.B., Verma, U.L. \& De Carlo, S.J. (1977) Secretion and reabsorption of uterine luminal fluid in rats. J. Reprod. Fert. 49, 183-187.

DANIEL, J.C. (1973) A blastokinin-like component from the human uterus. Fert. Steril. 24, 326-328.

Douglas, C.P., Garrow, J.S. \& Pugh, E.W. (1970) Investigation into the sugar content of endometrial secretion. J. Obstet. Gynaec. Br. Commonw. 77, 891-894.

EdWARds, R.G., TAlbert, L., ISRAElstam, D., Nino, H.V. \& JoHNSON, M.H. (1968) Diffusion chamber for exposing spermatozoa to human uterine secretions. Am. J. Obstet. Gynec. 102, 388-396.

Gornall, A.G., Bardawill, C.J. \& David, M.M. (1949) Determination of serum proteins by means of the biuret reaction. J. biol. Chem. 177, 751-766.

GravleE, L.C. (1969) Jet-irrigation method for the diagnosis of endometrial adenocarcinoma. Its principle and accuracy. Obstet. Gynec., N.Y. 34, 168-173.

Hall, H.H., Sedlis, A., Chabon, I. \& Stone, M.L (1965) Effect of intrauterine stainless steel ring on endometrial structure and function. $\mathrm{Am}$. J. Obstet. Gynec. 93, 1031-1041.

Hanks, G.E., Cassell, M., Ray, R.N. \& Chaplin, H. (1960) Further modification of the benzidine method for measurement of hemoglobin in plasma. $J$. Lab. clin. Med. 56, 486-498.

Hester, L.L., Kellet, W.W., Spicer, S.S., Williamson, H.O. \& Pratt-Thomas, H.R. (1970) Effects of intra-uterine contraceptive device on endometrial enzyme and carbohydrate histochemistry. Am. J. Obstet. Gynec. 106, 1144-1151.

Iritani, A., Gomes, W.R. \& VanDemark, N.L. (1969) The effect of whole dialysed and heated genital tract fluids on respiration of rabbit and ram spermatozoa. Biol. Reprod. 1, 77-82.

Joshi, S.G., KRAEMER, D.C. \& Chenault, C.B. (1970)
Effect of an intrauterine foreign body on lysosomal enzyme activity and white blood cell numbers in uterine washings of rats, baboons and humans. Contraception 2, 339-351.

Kar, A.B., Engineer, A.D., Goel, R., Kamboj, V.P., Dasgupta, P.R. \& Chowdhury, S. R. (1968) Effect of an intrauterine contraceptive device on biochemical composition of uterine fluid. Am.J. Obstet. Gynec. 101, 966-970.

KiRTON, K.T. \& Hafs, H.D. (1965) Sperm capacitation by uterine fluid or beta amylase in vitro. Science, N.Y. 150, 618-619.

Kulangara, A.C. (1976) Maintenance of plasmaderived proteins at much lower concentrations in the uterine lumen of the rabbit: a kinetic study of passage. J. Reprod. Fert. 46, 189-194.

LEWIS, B.K. \& KeTCHEL, M.M. (1973) Effects of female reproductive tract secretions on rabbit sperm. 3 . Acrosomal enzyme changes related to capacitation. Proc. Soc. exp. Biol. Med. 143, 540-544.

Lowry, O.H., Rosebrough, N.J., FARr, A.L. \& RANDALL, R.J. (1951) Protein measurement with the Folin phenol reagent. J. biol. Chem. 193, 265-275.

Lutwak-Mann, C., Boursnell, J.C. \& BennetT, J.P. (1960) Blastocyst-uterine relationships: uptake of radioactive ions by the early rabbit embryo and its environment. J. Reprod. Fert. 1, 169-185.

MaAthuis, J.B., Van Look, P.F.A. \& Michie, E.A. (1978) Changes in volume, total protein and ovarian steroid concentrations of peritoneal fluid throughout the human menstrual cycle. $J$. Endocr. (in press).

Martin, L., Hallows, R.C., Finn, C.A. \& West, D.G. (1973) Involvement of the uterine blood vessels in the refractory state of the uterine stroma which follows oestrogen stimulation in progesterone-treated mice. J. Endocr. 56, 309-314.

Nilsson, O. (1962a) Electron microscopy of the glandular epithelium in the human uterus. 2. Early and late luteal phase. J. Ultrastruct. Res. 6, 422-431.

Nilsson, O. (1962b) Electron microscopy of the glandular epithelium in the human uterus. 1. Follicular phase. J. Ultrastruct. Res. 2, 331-341.

Pappas, G.D. \& BlanchetTe, E.J. (1965) Transport of colloidal particles from small blood vessels correlated with cyclic changes in permeability. Invest. Ophthal. 4, 1026-1036.

PARR, E.L. \& Shirley, R.L. (1976) Embryotoxicity of leucocyte extracts and its relationship to intrauterine contraception in humans. Fert. Steril. 27, 1067-1077.

Peplow, V., Breed, W.G. Eckstein, P. (1973a) Studies on uterine flushings in the baboon. II. The effect of an intrauterine contraceptive device on certain biochemical parameters. Am. J. Obstet. Gynec. 116, 780-784. 
Peplow, V., Breed, W.G. Jones, C.M.J. \& Eckstein, P. (1973b) Studies on uterine flushings in the baboon. I. Method of collection, cellular composition, and protein electrophoretic profiles in animals with and without intrauterine contraceptive devices. Am. J. Obstet. Gynec. 116, 771-779.

Roberts, G.P., PARKer, J.M. \& Henderson, S.R. (1976) Proteins in human uterine fluid. J. Reprod. Fert. 48, 153-157.

ShiraI, E., IIzUKa, R. \& Notake, Y. (1972) Analysis of human uterine fluid protein. Fert. Steril. 23, 522-528.

Snedecor, G.W. \& Cochran, W.G. (1967) Statistical Methods, 6th edn, pp. 130-131. p. 194. Iowa State University Press, Ames, Iowa.

Trevelyan, W.E. \& Harrison, J.S. (1952) Studies on yeast metabolism. 1. Fractionation and microdetermination of cell carbohydrates. Biochem. J. 50, 298-303.

Weisman, A.I. (1951) The volumetric capacity of the human nulliparous uterus. Am. J. Obstet. Gynec. 61, 202-204.

Wolf, D.P. \& MastroianNi, L. (1975) Protein composition of human uterine fluid. Fert. Steril. 26, 240-247.

WYNN, R.M. \& HARRIS, J.A. (1967) Ultrastructural cyclic changes in the human endometrium. I. Normal preovulatory phase. Fert. Steril. 18, 632-648.

WYNN, R.M. \& WOOLLEY, R.S. (1967) Ultrastructural cyclic changes in the human endometrium. II. Normal postovulatory phase. Fert. Steril. 18, 721738.

Received 4 July 1977 